\title{
Experience with Rainwater Catchment Systems in Kenya and Botswana
}

\author{
H. J. McPHERSON AND J. GOULD \\ University of Alberta, Edmonton, Canada
}

\begin{abstract}
Rainwater catchment is a valuable but frequently neglected altemative a domestic water supply in the developing world. In the arid and semi-arid areas of Kenya and Botswana number of water supply programmes which depend wholly or in part on rainwater catchment are currently being implemented. This paper discusses this experience and describes the various construction techniques being used. It has been found that rainwater catchments has a number of very unique advantages and relatively few disadvantages. It is argued that more consideration should be given to the inclusion of rainwater catchment systems. especially in rural water supply programmes.
\end{abstract}

\section{INTRODUCTION}

The last decade has witnessed a growing interest. by international agencies and national governments in low-cost water systems as solutions to the water needs of the developing world. There have been several reasons for this. First, it has been realized that sophisticated solutions, such as pumping systems and treatment plants often associated with a reticulated supply, can simply not be afforded by many developing countries. Secondly, people are questioning whether high technology systems are the appropriate answer to the needs of the developing world, especially in rural areas where frequently there is no centralized government maintenance programme.

The water supply systems which are increasingly being built are those which promise to provide water at low cost and, more importantly, which can be operated and maintained by the users themselves.

In the water supply sector, major low cost technologies include handpump wells, gravity water systems and rainwater catchment. Wells equipped with handpumps exploit groundwater resources, and are perhaps the most universal technology in use today. Gravity water supply systems are the second most widely used low-cost technology, while rainwater catchment has been, to a considerable extent, largely ignored. However, in recent years there has been an increasing appreciation that rainwater catchment offers advantage over the other systems, and that in certain situations it may be the best answer.

Rainwater catchment has been used in East Africa for some time and a considerable body of knowledge about rainwater catchment has been accumulated.

This paper describes the current technology, the cost of the various alternative systems being constructed and the major advantages and disadvantages of rainwater catchment in East Africa.

\section{DEFINITION}

First, what is meant by rainwater catchment? A rainwater catchment is basically any system which collects, stores and supplies rainwater runoff for human needs. However, because this definition

Dr. McPherson is Professor of Geography at the University of Alberta. Edmonton, Canada, and has acted as a consultant on water supply and sanitation to a number of major international agencies.

Mr. Gould is a graduate student at the University of Alberta und has worked in Botswana and Nigeria.

Natural Resources Forum @ United Nations, New York, 1985 
could include such diverse systems as a puddle supplying livestock with drinking water or a hydroelectric dam supplying the water and energy, it is helpful to define these systems in a more precise manner.

Although there is much confusion and duplication of terminology, rainwater catchment systems (synonymous with rainwater collection systems) normally refer to small-scale systems providing individual households or single communities with a primary or supplementary water supply. In this paper three main types of rainwater catchment systems will be described. There are:

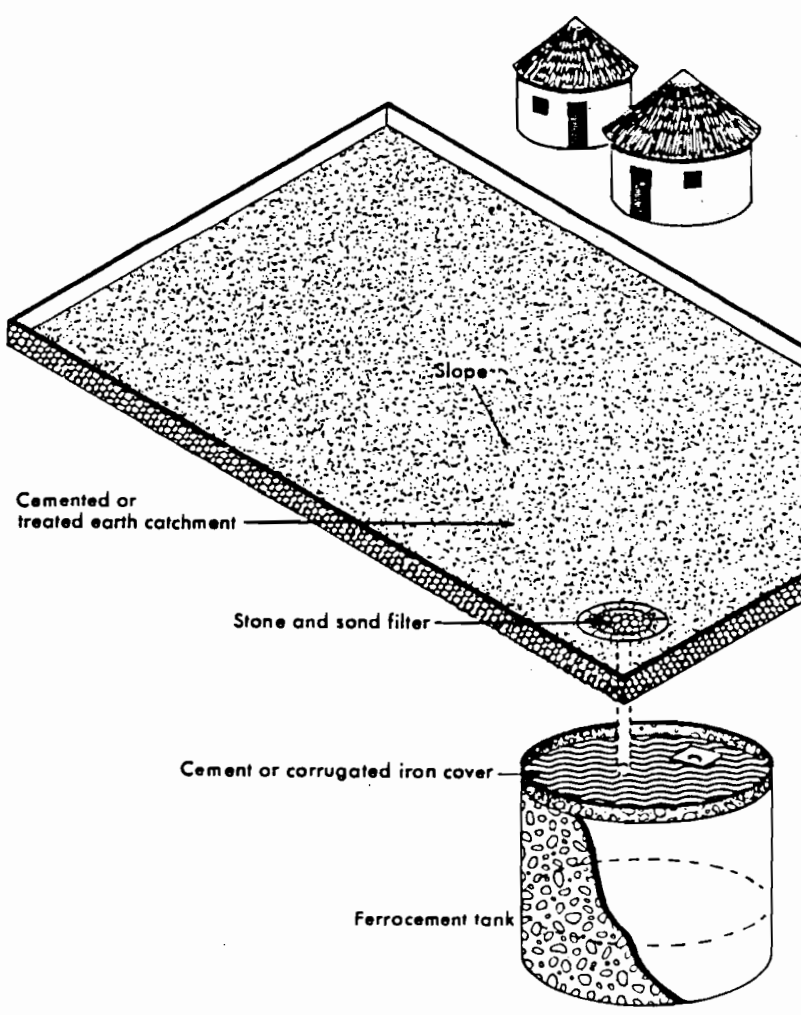

Fig. 2. Ground catchment system.
(1) Rock Catchments: systems for the collection, storage and supply of rainwater from untreated rock surfaces (Fig. 1),

(2) Ground Catchments: systems for the collection, storage and supply of rainwater from treated and untreated ground surfaces (Fig. 2) and

(3) Roof Catchments: systems for the collection. storage and supply of rainwater from roof surfaces (Fig. 3).

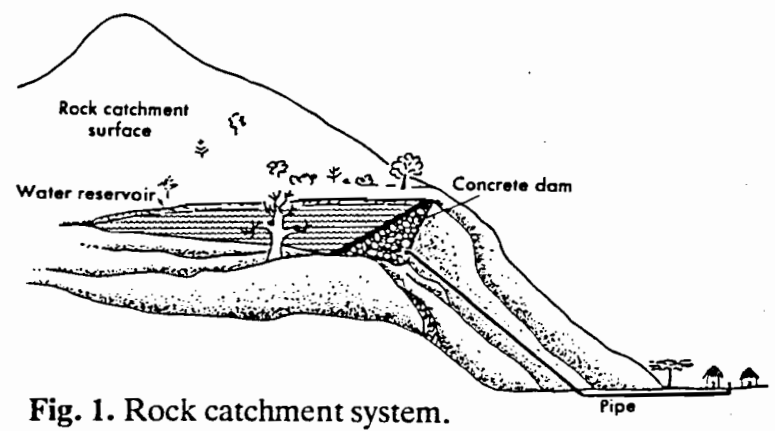

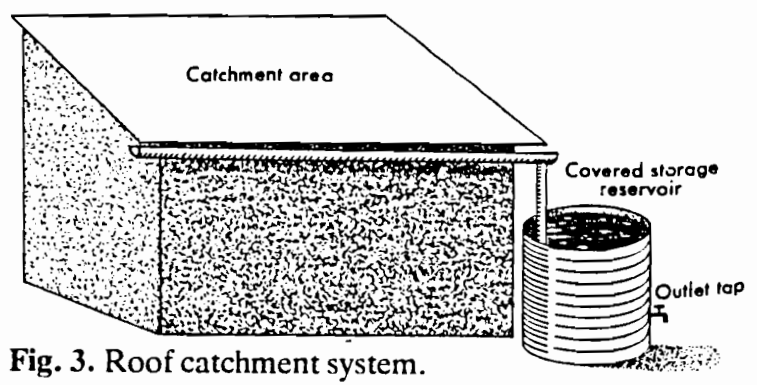


All of these systems consist of three components, a catchment area, a storage reservoir and an outlet for supply. In the case of rock catchment and roof catchment, the storage reservoir is normally above ground and the water is supplied through gravity flow via a pipe or tap. For ground catchments, however, the storage reservior is generally below ground and some method for extracting the water is necessary, either directly by hand or by pump.

\section{DETERMINING DEMAND, SUPPLY AND STORAGE}

The objective of a rainwater catchment scheme is to satisfy the demand for water as efficiently as possible.

The demand for water can be obtained from a user survey or a project design value can be estimated. Seven litres per day per capita is, for example, the minimum amount of water needed to sustain life. In many countries a per capita value of between 20 and $30 \mathrm{l} / \mathrm{d}$ serves a good indicator of daily water requirements.

Calculating the available supply and the size of the storage reservoir needed to meet the estimated demand is perhaps the most critical step in designing a catchment system. If the storage tank is built too small the system will run dry and the users will become disenchanted, if the storage tank is made too large this will greatly increase the cost and reduce affordability. It is therefore essential that an accurate estimate of the supply and the size of the needed storage tank by determined.

Two different estimates should be calculated for supply. The first estimate is the total amount of water available from the annual rainfall: this is simply the catchment area multiplied by the mean annual rainfall multiplied by the runoff coefficient. The second estimate is the most economically feasible rainwater supply system. To determine which system to use, it is necessary to compute the cost of the water which could be provided by storage facilities at different capacities.

A crude means of determining the storage capacity required for any particular rainwater catchment system is to determine the mean maximum length of the dry season (or mean maximum period without rain) and calculate the volume of water needed over this period. The volume needed is equivalent to the required storage.

A second method is the graphical mass curve method. Figure 4 illustrates the use of this method to determine the storage needed to provde a yearround supply of water. The graph is produced by plotting the cumulative rainfall runoff (rainfall $x$ catchment area $\times$ runoff coefficient) against time and by placing the time representing the steady consumption of this water tangentially above the mass curve. Then the most critical (driest period) in the data can be identified and the storage demand estimated.
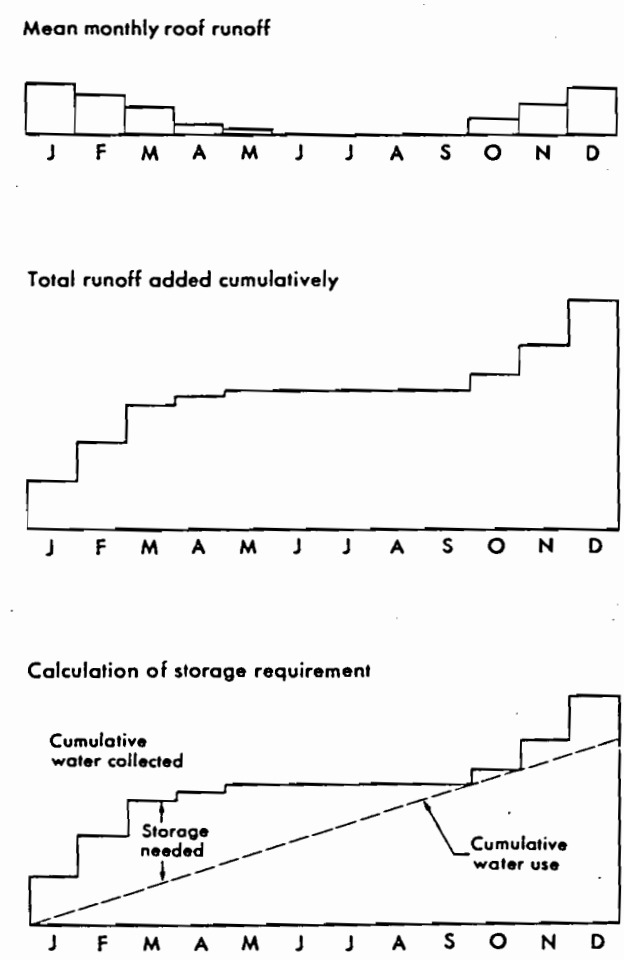

Fig. 4. Simplified mass curve analysis for determining rainwater tank storage capacity.

A more sophisticated method involves 'critical period analysis' where the actual rainfall data for the particular locality are analysed and critical periods in the rainfall record identified. The storage requirement needed to overcome the most critical period is determined. Although this 
method is slow and laborious when done graphically or when using a calculator, it can be carried out relatively quickly with the aid of a computer. Computer models for rainwater storage tank design have recently been developed by Perrens (1975) and Latham and Schiller (1984). The computer model approach allows considerable flexibility, as different levels of supply determined by percentage reliability of occurrence can be calculated for any given system. Figure 5 shows the level of supply associated with any given storage capacity at $95 \%$ and $100 \%$ realiabilities. for Mahalapye, Botswana. Both the storage and supply are given as fractions of the total useful runoff. Thus, a storage capacity equivalent to 0.4 multiplied by the toal available runoff would

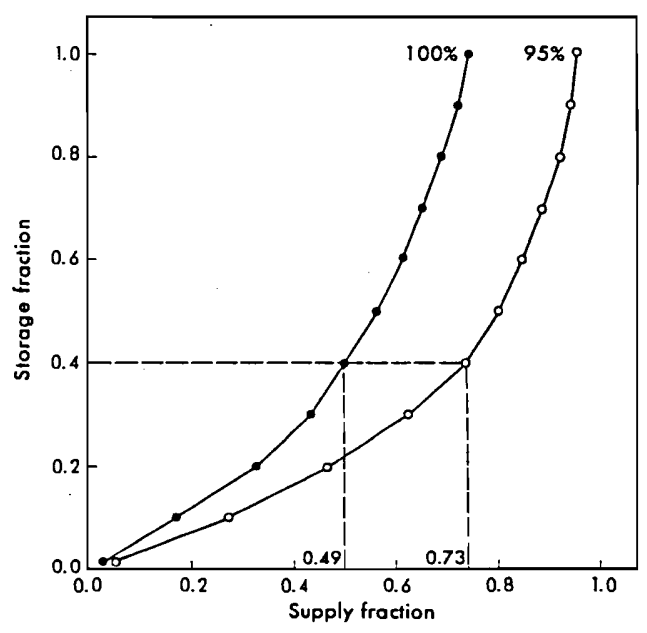

Fig. 5. Storage-supply curves ( $95 \%$ and $100 \%$ reliability) for Mahalapye, Botswana.

supply 0.73 of this runoff with a $95 \%$ level of reliability but only 0.49 with $100 \%$ reliability. Put another way, this means that a $4 \mathrm{~m}^{3}$ tank should yield $7.3 \mathrm{~m}^{3}$ annually for $95 \%$ of the time.

The computer model approach provides a very reliable method for estimating the appropriate storage tank size for any given climatic situation at whatever level of reliability is desired.

The capacity of the storage reservoir having been determined, the next step is to construct the catchment reservior.

\section{CONSTRUCTION}

The nature of the construction will obviously vary depending on whether a roof catchment, rock catchment or ground catchment scheme is being built. However, in all three an emphasis should be placed on building low-cost reservoirs where local inputs of labour and materials can be maximized. Cost is a key factor, and in East Africa considerable experimentation is currently under way to find the least expensive methods of building catchment systems.

\subsection{ROCK CATCHMENTS}

Reservoirs for rock catchments normally consist of a dam wall behind which an open reservoir stores the rainwater. Generally the surface area of the reservoir will be too large to make covering it economically feasible, despite the considerable evaporation losses which may be expected. In some cases it may be worthwhile to investigate the use of cetyl alcohol or other evaporation suppiessants. The dam is normally constructed of massive concrete, but recent experiments at Mutomo in Kenya by Nissen-Petersen (1985) have found that a series of buttressed, arched dams do the job just as well and require less material. In some instances tanks have been constructed for storage of rainwater at small rock catchments.

\subsection{ROUND CATCHMENTS}

Due to the fact that in ground catchment systems the catchment apron is at ground level, the storage reservoir always consists of a subsurface tank. Consequently, some method of extracting the water from the tank is required. Usually a rope and bucket or a pump is used.

Two low cost and successful methods of subsurface tank construction observed in both Kenya and Botswana are the lining of an excavated pit with either butyl rubber or ferro-cement. In Botswana a $700 \mathrm{~m}^{3}$ excavated butyl rubber lined tank. used for irrigation was observed at the Foresty Brigade in Serowe. It was still functioning in 1983 after 7 years of operation, although it now requires cleaning. The lining of excavated pits in consolidated soils with butyl rubber is one of the simplest and cheapest methods of ground catchment tank construction, and this approach has been recommended for application in Africa 
by Bateman (1971).

However, a more widely used method is the lining of the ground catchment tank with ferrocement. In Botswana more than 400 tanks of this type have already been constructed, and under the Ministry of Agriculture's Arable Lands Development Program (ALDEP) several hundred more are planned. A detailed description of their construction is given in Whiteside (1982) in a leaflet produced for local builders to show them how to construct the tanks. Basically, the method involves lining a cylindrical pit with chicken wire and plastering this with three layers of mortar. The design also includes a concrete base and corrugated iron cover (Fig. 6). Tanks have been successfully constructed with a capacity of between 5 and $30 \mathrm{~m}^{3}$. The Botswana Technology Centre is presently experimenting with tanks of up to $60 \mathrm{~m}^{3}$ for roof catchment.

The ferro-cement tank was developed and designed for the collection of rainwater from traditional threshing floors. These plastered mud floors are normally up to $150 \mathrm{~m}^{3}$ in area and are found at most homesteads where crops are grown. The construction of permanent cement catchment aprons is preferable in terms of the quantity and quality of water which may be collected, but adds considerably to the cost of the system. For a $15 \mathrm{~m}^{3}$ tank the cost is currently around US $\$ 350$. If the catchment area is cemented, the cost of the complete system, catchment area and the tank is about US $\$ 500$.

To help to reduce costs, no pump is included in the design of these tanks. The water is extracted using a rope and bucket. A number of experts have expressed concern about the quality of water from these tanks (Classen, 1980; Maikano and Nyberg, 1981; Whiteside, 1982). Bacteriological analysis of water from them (Gould, 1984) revealed faecal coliform counts of between 6 and 1000 in each $100 \mathrm{ml}$ sample. Although it has been recommended Whiteside (1982) that water from the tanks be boiled before drinking, few tank owners have taken this advice due to the lack of firewood and the inconvenience.

\subsection{ROOF CATCHMENTTANKS}

In contrast to ground and rock catchment systems where storage reservoirs always have to be constructed on-site, for roof tanks the option exists of either purchasing a factory-built tank or constructing one on the site.

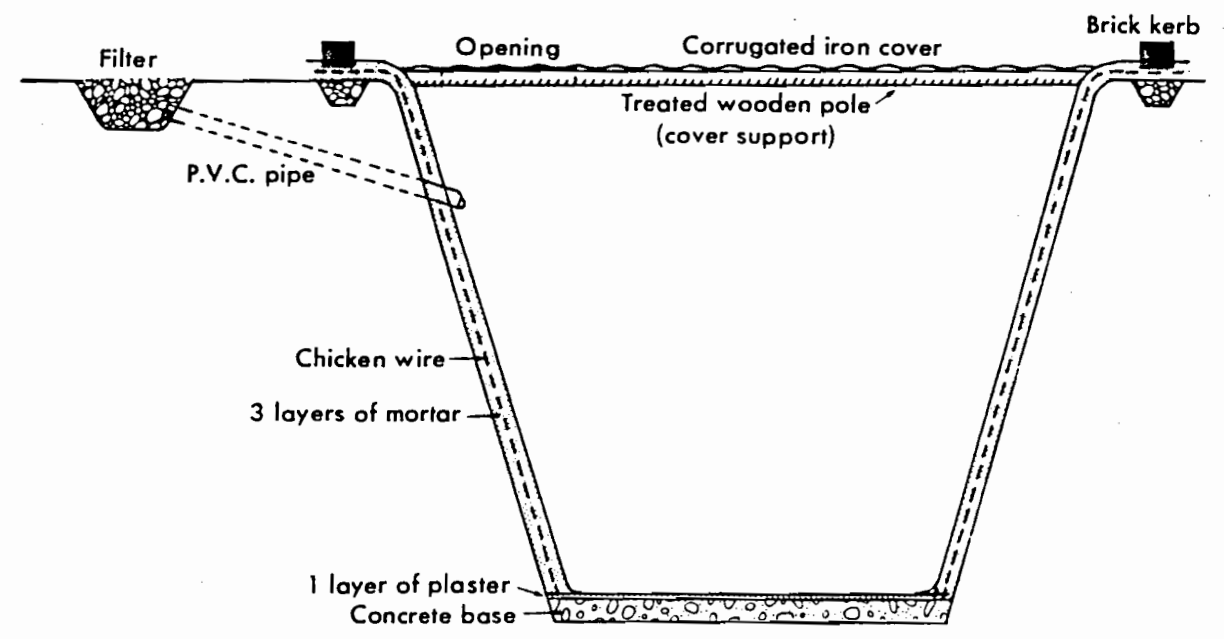

Fig. 6. Construction of ground catchment cement tank (cross-section). 


\subsubsection{Factory-built catchment tanks}

Probably the majority of roof catchment tanks currently in use in Africa are factory-built. Although the most common type of catchment tank is the $200 \mathrm{l}$ oil drum, these are too small to provide for anything more than a few days of storage. Most large factory-built catchment tanks are of galvanized corrugated iron and are seldom larger than $10 \mathrm{~m}^{3}$. The main disadvantage of corrugated iron tanks is that the tanks themselves or the steel from which they are produced is imported, and therefore the tanks represent a capital-intensive solution which drains developing countries of foreign exchange. The relatively short life-expectancy of these tanks is another disadvantage. Watt (1978) suggests most corrugated iron tanks last for 5-10 years.

Galvanized tanks do, however, offer certain distinct advantages over other types of roof catchment tanks. The most obvious of these is the convenience of installation. However, the relatively short life-expectancy, especially in coastal areas due to salt in the air, does reduce the economic advantage of galvanized tanks in relation to those made in cement. Although the life-span of a galvanized tank depends on the degree of preventative maintenance adopted, such as painting and cleaning, the gauge and quality of metal used to construct the tanks also determines their life-span. It seems clear that because many of the galvanized tanks installed in the 1950s and into the early-1970s are still operating whereas many of those installed in the late-1970s and 1980s are already leaking, that the quality of the tanks being produced by manufacturers in Kenya and South Africa (where Botswana's tanks are imported from) has deteriorated.

\subsubsection{Catchment tanks constructed on-site}

Standard engineering wisdom normally results in over design of structures to minimize the risk of failure. However, when small-scale roof catchment tanks are constructed in this way the result is a very expensive tank which is not worth the added cost because the tank is unlikely to cause any serious damage in the event of failure. For this reason considerable time and effort has been invested into the development of low-cost designs. Although these designs do not adhere to the stringent standards normally applied by civil engineers, they are nevertheless more than adequate.

In southeast Asia, one of the successful designs in use in Thailand and Indonesia is the bamboo reinforced tank. In Africa the absence of bamboo in most areas has led to designs based on ferrocement, cement blocks and the use of basketwork frames. Among the dozens of designs which have been developed for the construction of roof catchment tansk, four stand out as having been successful both in terms of cost effectiveness and operation. These include cement jar tanks, ghala baskets, concrete ring tanks and ferro-cement tanks.

Cement jar tanks. Cement Jar Tanks are constructed using a hessian or cloth bag mould, which is placed on a precast concrete foundation slab, filled with sawdust, grass, sand or any other appropriate filler, and is then plastered with mortar. Once the mortar has set, the filler and mould are removed. These tanks have been constructed by the hundred in Kitui district, Kenya, with the support of the Roman Catholic Church and other developed agencies. Cement jar tanks can be built up to $10 \mathrm{~m}^{3}$ according to Byrne (1983), but if they are larger than 3 or $4 \mathrm{~m}^{3}$ they must be reinforced with chicken wire or fencing wire. More-detailed descriptions of their construction are given by Nissen-Petersen (1982), Byrne (1983) and McPherson et al.

(1984).

Ghala basket tanks. More than 1000 ghala basket tanks have been constructed by community groups in Kenya, working under the guidance of UNICEF. The design involves applying mortar to the inside and outside of a basketwork frame. Tanks up to $6 \mathrm{~m}^{3}$ can be easily constructed employing only semi-skilled labour. It is essential that enough cement be used and that the outside as well as the inside of the tank is property plastered. In North Kituim. Kenya, some poorly constructed tanks have suffered severe leakage problems. In contrast, the tanks built by UNICEF in Karai have performed very well. A detailed description of the materials required and the construction technique is given by Nissen-Petersen (1982) and McPherson et al. (1984).

Concrete ring tanks. Concrete ring tanks are a relatively new design which have the advantage of being easy to construct. In Machakos district 
350 were built in the space of only 12 months under guidance from the local Roman Catholic Diocese Development Office. The rapid acceptance and diffusion of the tanks partly reflects the ease with which they can be constructed as well as their low cost. A $4 \mathrm{~m}^{3}$ tank costs around US $\$ 100$ while a $13 \mathrm{~m}^{3}$ tank (the largest so far constructed) costs US $\$ 350$.

The construction of these tanks is accomplished using two concentric corrugated iron ring moulds made by simply bolting curved segments together. The larger mould has a diameter of 10-20 cm more than the smaller one, so when the two are centred on top of a precast concrete base there is a space into which the concrete is poured. This design is particularly suitable for areas where aggregate is locally available and can be collected and carried to the site by self-help labour. When the first ring of concrete has set, the corrugated iron moulds are removed and placed on top of the previously completed concrete ring. This process is repeated until a required number of rings (usually three or four) have been completed. The tank is plastered inside and out with concrete and a ferro-cement cover cast for the tank.

Ferro-cement tanks. The advantage of ferrocement tanks over the three preceding designs is that extremely large tanks can be built using the technique. According to Watt (1978) it is possible to construct surface ferro-cement tanks with volumes of $400 \mathrm{~m}^{3}$. In Kenya, tanks with volumes of up to $120 \mathrm{~m}^{3}$ have been built at Mutomo. For smaller tanks a single cylindrical corrugated iron mould is used. This is normally tansported in four segments to the site and bolted together. Chicken wire is coiled around the mould, and loops of fencing wire wrapped around this to act as reinforcement. Mortar is plastered on the outside of the mould and. when it is finally set, and mould is unbolted and removed. Additional mortar is then plastered on the inside of the tank wall and the base. A highly detailed step-by-step account of this procedure is given in Watt (1978). For larger tanks a moveable mould can be used as this allows small portions of the tank wall to be constructed at a time and also avoids the high costs of a very large mould.
Other tank designs recently developed in Kenya which deserve mention are two varieties of ferrocement tanks which are built using a weldmesh framework. The first of these is a design developed by a commercial enterprise called 'ferrocraft' in Kilifi. The technique consists of making a cylindrical frame of weldmesh and wrapping this with two layers of chicken wire before applying mortar to the inside and outside of the framework. More than 100 tanks of capacity $6 \mathrm{~m}^{3}$ have been produced in this way and, although technically the tanks are very good and extremely durable, they are more expensive than the other designs discussed, selling for about US $\$ 350$ each including transport to the site and a 2-year guarantee.

A second ferro-cement weldmesh design is currently being developed by the African Medical Research Foundation (AMREF). This design involves the use of papyrus mat shuttering which is placed on the inside of the weldmesh framework before it is plastered. When the mortar has set the shuttering is removed. Preliminary results suggest that this is an inexpensive and convenient method.

Finally, Nissen-Petersen (1982) in his book on rain catchment and rural water supply in Africa, describes a concrete block tank with a corrugated iron roof which can be built relatively cheaply if the blocks are made on-site using community labour.

\subsection{COST COMPARISON}

Table I shows the cost of a number of different types of roof catchment tanks in Kenya and Botswana. A number of generalizations can be made from the table. First, the smaller tank tends to have a higher cost per unit volume. Ironically, most poor people buy those because they cannot afford the much larger, but more expensive, tank that they really require. Second, it can be seen that although ferro-cement and concrete ring tanks are among the cheapest, they are not significantly cheaper than corrugated iron tanks. Although the potential durability of the ferro-cement tank is greater than the corrugated iron tank, this is only the case where ferro-cement tanks are properly constructed and maintained. Where good workmanship cannot be guaranteed it may be cheaper in the long run to install corrugated iron tanks. In coastal areas, however, due to the rapid rusting which is caused by the salty sea air, ferro-cement 
TABLE I

Cost comparison of different types of catchment tanks in Kenya and Botswana (in 1984 US \$)

\begin{tabular}{|c|c|c|c|}
\hline Type of tank & $\begin{array}{c}\text { Volume } \\
\left(m^{3}\right)\end{array}$ & $\begin{array}{l}\text { Mean cost } \\
\left(U S \$ / m^{3}\right)\end{array}$ & Comments \\
\hline $\begin{array}{l}\text { Galvanized oil drum (Kenya) } \\
\text { Galvanized oil drum (Botswana) }\end{array}$ & $\begin{array}{l}0.2 \\
0.2\end{array}$ & $\begin{array}{c}100 \\
112.5-225\end{array}$ & $\begin{array}{l}\text { This is the most common type of storage tank } \\
\text { used. Although cheap, it is too small for most } \\
\text { purposes }\end{array}$ \\
\hline $\begin{array}{l}\text { Corrugated iron (Kenya) } \\
\text { Corrugated iron (Botswana) }\end{array}$ & $\begin{array}{c}1 \\
5 \\
10 \\
2.25 \\
4.5 \\
9\end{array}$ & $\begin{array}{l}60 \\
26 \\
24 \\
50 \\
35 \\
30\end{array}$ & $\begin{array}{l}\text { Must be transported to site } \\
\text { Not very durable } \\
\text { Rust easily, especially in marine environment }\end{array}$ \\
\hline Brick/cement (Kenya) & $1-1000$ & $40-60$ & This cost assumes a standard engineering design \\
\hline Ghala basket (Kenya) & $1-8$ & $17-40$ & $\begin{array}{l}2000-3000 \text { have already been constructed in } \\
\text { Kenya with varying degrees of success }\end{array}$ \\
\hline Cement jars (Kenya) & $1-10$ & $33-50$ & Larger jars require wire reinforcement \\
\hline $\begin{array}{l}\text { Ferro-cement (Kenya) } \\
\text { Ferro-cement (Botswana) }\end{array}$ & $\begin{array}{c}1-200 \\
10\end{array}$ & $\begin{array}{c}13-26 \\
40\end{array}$ & $\begin{array}{l}\text { This new rapidly expanding technology has the } \\
\text { advantage of producing relatively large tanks }\end{array}$ \\
\hline Concrete ring (Kenya) & $1-25$ & 23 & $\begin{array}{l}\text { These tanks are simpler to build than ferro- } \\
\text { cement }\end{array}$ \\
\hline Subsurface ferro-cement (Botswana) & 20 & 20 & $\begin{array}{l}500 \text { have already been built in Botswana. } \\
\text { Although these tanks are cheap, problems of } \\
\text { water quality exist }\end{array}$ \\
\hline
\end{tabular}

and concrete ring tanks are greatly superior to corrugated iron tanks.

\section{EXPERIENCE WITH RAINWATER CATCHMENT}

Some broad generalizations can be made with respect to experience with rainwater catchments in Kenya and Botswana. In both Kenya and Botswana, rainwater catchment has been applied mainly in the arid and semi-arid areas where there is an urgent need for water and where surface water and groundwater are either scarce or nonexistent. An exception to this is in Western Kenya, where some small individual roof catchments systems are in operation. However, these employ the simplest of storage tanks - oil drums or corrugated iron tanks.

Bacteriological analysis of ground catchment tank water in Botswana showed that in the majority of cases the water has unacceptably high levels of faecal coliforms. Faecal coliform counts in eight catchment tanks ranged from a low of 6 to a high of 1000. In most tanks the faecal coliform count was above 150 . In contrast, analysis of water quality in 13 roof catchment tanks indicated a zero faecal coliform count and total coliform count which indicated that the water presented no health risk.

Some problems were noted with the application of rainwater catchment systems in both countries. These tended to be technical due to a poor understanding of what was involved in the design and construction of rainwater catchments. The main problems identified were the following. 
(1) The storage tanks were too small. This was usually because the householder or project organizer did not know how to estimate storage needs accurately. In Kenya, for example, the ghala baskets were often much too small, and to assure an adequate supply several baskets were needed.

(2) The tanks leaked or did not hold water. There were several reasons for this. A common fault was that the ferro-cement tanks were not properly cured. Ferro-cement tanks need to be kept moist for several days if they are to cure correctly and retain water. In other cases the cement mix was not correct and leakage occurred. Some breakage was also noted in ferro-cement tanks built at a central location and transported to the site.

(3) Some tanks were not properly covered. A good cover is essential to reduce evaporation and to protect the water from contamination.

\subsection{ADVANTAGES AND DISADVANTAGES OF RAINWATER CATCHMENT}

Rainwater catchment has a number of distinct advantages, which in some situations make it a more acceptable technology than the others available. The advantages can be summarized as follows.

(1) Rainwater is clean and free of disease-causing pathogens. Roof catchment systems, so long as the tank is covered, provide a source of safe water. Ground catchment systems, if bare ground is used as the catchment apron, are much more likely to yield contaminated water, as was found in the ALDEP ground catchment tanks in Botswana.

(2) With roof catchment systems the water is available at the home. It can even be piped directly into the house. In western Kenya, where protected springs are being developed as a source of water, the springs are located at the bottom of deep valleys and the householders must carry the water up several hundred meters along a steep path. This is much more inconvenient than a roof tank beside the house. A disadvantge of ground catchment schemes is that they usually serve a number of families and some walking is necessary to collect water.
(3) With roof catchment, the householder owns the system. There are tremendous advantages to this. The householders is much more likely to look after the tank and maintain it if it belongs to him.

(4) Operation and maintenance costs are low with roof catchment schemes, and usually the owner can do all the work himself. This removes the need for a government maintenance programme and all the costs associated with such a service. Experience in both groundwater projects and gravity water systems in Africa has shown that some form of a government central maintenance programme is usually necessary.

(5) The technology is simple and all spare parts or materials necessary to make repairs can be obtained locally. This contrasts with handpump wells programmes. In Kenya, for example, there are no handpumps made locally except on an experimental basis. Consequently, getting spares and repairing handpumps is a serious problem and a number of handpump wells programmes have failed because the handpump broke down and were never repaired. Gravity water systems can also break down, and in Kenya there are examples of schemes which no longer function because of burst pipes or poorly designed and built systems.

These are several disadvantages to rainwater catchment systems. The prime disadvantage is cost. Storage tanks, as has been seen, are expensive to build so the intial capital outlay is large. This is the reason why so much experimentation is taking place in East Af:ica to develop an inexpensive storage tank. Besides the storage tank, there may be other costs depending on whether the system is a ground, roof or rock catchment. A roof with adequate guttering may have to be built because the existing roof is either thatched, too small to provide an adequate supply or has no guttering. In ground catchment systems an apron may have to be constructed of concrete or plastic and in rock catchment schemes a pump may be necessary.

Another disadvantage with rock and ground catchment schemes is that the water may require treatment before it can safely be drunk. 


\section{CONCLUSIONS}

In Kenya and Botswana rainwater catchment is mainly practised in the arid and semi-arid areas, and it is still regarded as a technology to be utilized if water cannot be obtained in other ways. This is unfortunate, as rainwater is convenient and offers great promise in humid areas as well.

Significantly, in both Kenya and Botswana all of the really large projects are exploiting ground or surface water sources. Rainwater catchment is the poor relation, and such schemes as there are are largely the domain of non-government organizations and are relatively small in scope.

However, a positive sign is that some of the major rural water supply programmes are starting to include some rainwater catchment as an element. In Kenya, for example, the German Technical Aid Programme is supporting roof catchments in the Lake Kenyatta resettlement progect; the European Economic Community is interested in roof catchments in the Machakos district and Finnida has investigated the possibility of roof catchments in their extensive rural water supply programme in west Kenya. These are hopeful signs and suggest that in the future rainwater catchments may play a more significant role in supply desperately needed water.

In the next several decades in the developing world, and especially in Africa, we are going to be faced with a dramatic water crisis. In order to meet this crisis, water will have to be provided as cheaply as possible from systems that are going to have to be largely maintained by the users.

In those efforts to provide water, rainwater should not be neglected. Because of its unique advantages of technical simplicity and convenience, rainwater catchment can make a major contribution to supplying the water needs of many people.

\section{REFERENCES}

Alcock, P. G. 1983. A water supply strategy for the Inadi Ward, Vulindulela District, Kwazulu: A research framework. Subsistance Agriculture Study Group, University of Natal. 13 pp.

Bateman, G. H. 1971. Intermediate technology and rural water supplies. In Proc. Conf. Rural Water Supply in East Africa, 5-8 April 1971, Dar Es Salaam, (Ed. Tschenner), pp. 215-8.

Byrne, H. 1983. Clean water in Kola. Waterlines, 1(1), pp. 21-3.

Classen, G. 1980. Small scale rural water supply. Ministry of Agriculture, Bag 003, Gaborone. 80 pp.

Farrar, D. M. 1974. Aspects of water supply and conservation in some parts of Africa. Unpublished Ph.D. Thesis, University of Manchester.

Farrar, D. M. and Pacey, A. J. 1974. Catchment tanks in southern Botswana: A review Africa Fieldwork and Technology Report No. 6, 13 pp. (Available from ITDG, 9 King St, London).

Feachem, R. G. et al. 1978. Water, Health and Development: An Interdisciplinary Evaluation. Tri-Med Books, London, $218 \mathrm{pp}$.

Fortmann, L. and Roe, E. 1981. Water use in eastern Botswana: Policy guide and summary of the water points survey. Ministry of Agriculture, Gaborone, $96 \mathrm{pp}$.

Gould, J. E. 1984. Rainwater catchment systems in Botswana, present, past and future. Waterlines, 2(4), pp. 14-8.

Gould, J. E. 1985. An assessment of rainwater catchment systems in Botswana. Unpublished M.Sc. Thesis, University of Alberta, $222 \mathrm{pp}$.

Grover, B. 1971. Harvesting precipitation for community water supplies. Unpublished Report, World Bank. $110 \mathrm{pp}$.

Hall, N. 1982. Water collection from thatch. Waterlines, 1(1), pp. 23-6.

ITDG 1969. The introduction of rainwater catchment tanks and micro-irrigation to Botswana. Intermediate Technology Development Group, 9 King St, London. 74 pp.

ITDG 1971. Report on the state of the Botswana catchment tank project after three years of operation. Intermediate Technology Development Group, 9 King St, London. 14 pp. (Contribution No. 173, California Water Resources Centre, University of California at Davis. 55 pp.)

Latham, B. 1984. Rainwater collection activities in Indonesia and Thailand. Report to CIDA, Ottawa, $132 \mathrm{pp.}$

Latham, B. and Schiller, E. J. 1984. Rainwater collection systems: A literature review. Civil Engineering Department, University of Ottawa. 32 pp. 
Maikano, G. J. and Nyberg, A. 1981. Rainwater catchment in Botswana. In Rural Water Supply in Developing Countries, Proceedings of Training Workshop August 5-12, 1980, Zomba, Malawi. Ottawa/IDRC. Publication 167e, pp. 13-7.

McPherson, H. J. et al. 1984. Low cost appropriate water and sanitation technologies for Kenya. Report to Ministry of Water Development, Nairobi, Kenya, Cowater International, Ottawa, 225 pp.

Nissen-Petersen, E. 1982. Rain Catchment and Water Supply in Rural Africa. Hodder and Stoughton. 83 pp.

Nissen-Petersen, E. 1985. Water from rocks. Waterlines, 3(3), pp. 8-13.

Omwenga, J. M. 1984. Rainwater harvesting for domestic water supply in Kisii, Kenya. Unpublished M.Sc. Thesis, Tampere University, Finland. 132 pp.

Pacey, A. 1977. Water for the Thousand Millions. Pergamon Press, London. 58 pp.

Perrens, S. J. 1975. Collection and storage strategies for domestic rainwater supply. In Hydrologic Symposium Proceedings, Armidale, NSW, Australia, pp. 168-72, 257-65.

Thiadens, A. 1983. Catholic Diocese of Machakos Development Office-Water engineer. Unpublished Internal Report. P.O. Box 640, Kachakos, Kenya, 17 pp.

UNEP 1983. Rain and Stormwater Harvesting in Rural Areas. Published for UNEP by Tycooly International Ltd, Dublin. 238 pp.

Watt, S. B. 1978. Ferrocement Water Tanks and their Construction. ITG Publications, 9 King St, London. 118 pp. Whiteside, M. 1982. How to build a water catchment tank. Mahalapye Development Trust (Botswana). Government Printers, Gaborone. 82 pp. 